\title{
ТРАНСФОРМАЦИЯ ФИНАНСОВОЙ СФЕРЫ РЕГИОНОВ РФ В УСЛОВИЯХ НАРАСТАНИЯ ВНЕШНИХ УГРОЗ
}

\section{Захарчук E.A.}

В последние годы угрозы сочиально-экономическому развитию как Российской Федерации в ичелом, так и отдельным регионам нарастают в значительной степени. В первую очередь это отражается на финансовой сфере, поскольку политика санкций в отношении России, в первую очередь, основана на блокировании возможностей использования различных финансовых инструментов за рубежом. Дальнейшее нарастание угроз может привести к различным формам чрезвычайных ситуаций в экономике и финансовой сфере. В то же время, малоизученным остается вопрос влияния специиальных режимов на финансовую сферу отдельных регионов, которое может быть разнородным в зависимости от возможностей территорий.

Цель исследования - выделить для финансовой сферы отдельных регионов возможные последствия, связанные с нарастанием внешних угроз и введения специиальных режимов хозяйствования.

Методы исследования: в работе использованы методы анализа и исторических аналогий, применены общенаучные методы сравнений и экстраполяциии.

Результаты: на основе обобщения зарубежсного и российского опьта введения экономических санкиий против отдельных стран, выделены наиболее вероятные виды санкционных режимов против России в финансово-экономической сфере. Также автором определен вероятный сиенарий изменений в финансовой сфере в случае введения специальных режимов хозяйствования в РФ, а также возможное влияние на отдельные регионы РФ. Вылелены параметры финансовых ограничений и основные характеристики функционирования денежно-кредитной системы в данные периоды времени, 
определены базовые условия изменений в сочиально-экономической сфере регионов РФ.

Область применения результатов: полученные результаты могут быть использованы в работе органов государственной власти при учете последствий от введения санкций и чрезвычайных режимов в региональной привязке.

Ключевые слова: санкции, чрезвычайные режимы; регионы РФ; финансовая система; внешние угрозы.

\section{THE FINANCIAL SPHERE TRANSFORMATION OF THE RUSSIAN FEDERATION'S REGIONS IN THE CONDITIONS OF INCREASING EXTERNAL THREATS}

\section{Zakharchuk E.A.}

In recent years, threats to the socio-economic development of both the Russian Federation as a whole and individual regions have been growing to a significant extent. This is primarily reflected in the financial sector, since the policy of sanctions against Russia is primarily based on blocking the possibilities of using various financial instruments abroad. A further increase in threats can lead to various forms of emergencies in the economy and financial sphere. At the same time, the question of the influence of special regimes on the financial sphere of individual regions, which can be heterogeneous depending on the capabilities of the territories, remains poorly understood.

The purpose of research - to determine the possible consequences of the financial sector in some regions due to the increase of external threats and the introduction of special modes of management.

Research methods: methods of analysis and historical analogies are used in the work, general scientific methods of comparisons and analogies are applied.

Results: Based on the generalization of foreign and Russian experience in introducing economic sanctions against individual countries, the 
most probable types of sanctions regimes against Russia in the financial and economic sphere have been identified. The author also identified a likely scenario of changes in the financial sector in the event of the introduction of special economic regimes in the Russian Federation, as well as a possible impact on certain regions of the Russian Federation. The parameters of financial constraints and the main characteristics of the functioning of the monetary system in these periods of time are highlighted, the basic conditions for changes in the socio-economic sphere of the regions of the Russian Federation are determined.

Scope of the results: the results obtained can be used in the public authorities, taking into account the consequences of sanctions and extraordinary modes in regional binding.

Keywords: sanctions; emergency regimes; regions of the Russian Federation; financial system; external threats.

\section{Введение}

На протяжении многих веков Россия испытывала различные ограничения стороны других государств в экономической, технической, торговой, политической и т.д. сферах, направленных на ухудшение условий хозяйственной деятельности внутри государства. В эти же столетия наша страна учувствовала во множестве вооруженных конфликтов как вблизи своих границ, на своей территории, так и в отдаленных уголках мира. Все это не могло отразиться на экономическом развитии государства, поскольку любые ограничения, тем более такого сильного характера, не могут сказаться на уровне и характере развития экономики любой страны. Наиболее сильные последствия повлекли участие нашей страны в Первой и Второй Мировых войнах, которые нанесли катастрофический ущерб по экономическому развитию всего народного хозяйства, прежде всего в промышленности и благосостоянию населения. В последние годы перед Российской Федерацией стали нарастать угрозы втягивания страны в новые конфликты, как на военном уровне, так и в сфере экономики. В то же время, в мировой экономике за последние десятилетия выросла роль финансовой сферы, как всеобъемлющего 
индикатора и проводника экономического развития, и недооценка трансформаций, происходящих в финансовом секторе в условия нарастания угроз, недопустима. Именно поэтому санкционное давление, оказываемое на Российскую Федерацию в последнее время, касается в значительной мере именно финансовой сферы, поскольку такой подход позволяет с минимальными затратами осложнить развитие не только всей страны, но и отдельных регионов России.

В общепринятом смысле под экономическими санкциями (торговые или финансовые) понимаются некие экономические мероприятия запретительного характера, которые могут быть использованы либо группой стран (например, санкции ООН), либо несколькими или одной страной против какого-либо субъекта (индивид, компания, отрасли, страна и т.д.). Цели санкций могут быть обширны - от экономического давления в целях протекционизма, до принуждения к изменению государственного строя.

Что касается чрезвычайных положений как в общественной жизни, так и в экономике, то в Конституции Российской Федерации предусмотрены наряду с обычным (общим) также два особых правовых режима: правовой режим чрезвычайного положения (ст. 56, 88) и правовой режим военного положения (ст.87). В данной работе мы рассматриваем именно режим военного положения, поскольку режим чрезвычайного положения больше относится к «техническим» событиям, предполагающим ограниченное применение как во времени, так и месте действия. Режим военного положения условно делится на два этапа: это этап мобилизации, при котором происходит подготовка к военному положению и собственно военное положение, при котором возможны как ограничение как прав и свобод граждан, так и перенастройка всей экономики под нужды военного времени.

Исследования, проводимые по данному вопросу можно разделить на два блока: во-первых, посвященные правовому статусу чрезвычайных режимов, во-вторых, описывающих влияние на экономику при введении таких режимов.

В первом блоке, В.В. Алешин в своей статье [1] рассматривает правовые основы применения и использования режима военного по- 
ложения и режима чрезвычайного положения. Также приведена международная практика использования этих режимов, делается вывод о разнообразии понимания и наполнения чрезвычайных режимов в разных странах. Там же выделены принципы введения чрезвычайного положения, при помощи которых фиксируются объективные закономерности регламентации и применения чрезвычайных режимных мер. В работе [2] разделяется статическое и динамическое состояние административно-правового режима военного положения. Под статическим состоянием понимается мирное время, когда происходит формирование теоретической модели военного положения, законодательные процедуры разработки и принятия соответствующего акта, а также прекращение действия военного положения. Все остальное, с момента введения военного положения и последующие действия по его реализации, по мнению автора исследования, относится к динамическому проявлению данного правового режима. В статье В.Н. Григорьева [3] проводится анализ системы чрезвычайного законодательства в Российской Федерации. При этом автор выделил ряд противоречий с Конституцией Российской Федерации и действующим федеральным конституционным законодательством, и предложил ряд подходов к решению правовых коллизий. Сравнительный анализ правового режима военного положения Российской Федерации и Республики Беларусь проводится в работе [4] Несмотря на схожесть правовых режимов двух стран, автор выделяет и различия между ними, основные из них - это противоречие по вопросам цензуры с конституциями России и Беларуси.

С экономической точки зрения, как правило, в литературе проводится исторический опыт организации народного хозяйства в военное время, финансовые и управленческие аспекты которого приведем ниже.

Так, например, в работе А.Н . Сорокина [5] рассматриваются вопросы организации науки и научных исследований в годы Великой отечественной войны, на примере города Томск. Отмечается, что после эвакуации промышленных предприятий и научных организаций в населенные пункты Урала и Сибири, значительная часть усилий 
научных сотрудников была направлена на решение проблем военной промышленности в части организации и обеспечения производства. Этому способствовала высокая концентрация научных кадров в данных городах, например на 130 тыс. жителей г. Томска во время войны находилось порядка 900 профессоров и доцентов. В другой работе [6] рассматриваются вопросы трудового законодательства в период ВОВ, основанного на введении режима военного времени. Среди прочих были выделены следующие особенности «трудовой повинности»: усиление централизованного регулирования социально-трудовой сферы, принудительный труд, мобилизация трудовых резервов (в том числе инвалидов), сокращение времени отдыха и применение сверхурочных работ, ужесточение трудовой дисциплины с наказанием уголовной ответственностью.

Исследование влияния военного положения в период первой мировой войны на экономику Оренбургской области представлено в работе [7]. В ней отмечается, что значительная часть трудоспособного мужского населения было призвано на фронт, в результате чего сократилось производство продукции сельского хозяйства, а цены на основные продукты питания выросли в 5-6 раз перед революцией 1917 года. Несмотря на это, заработные платы рабочих и крестьян практически не выросли, что привело к росту социальной напряженности и волнениям среди местного населения. В работах $[8,9]$ рассмотрены условия планирования хозяйственной деятельности СССР в условиях военной мобилизации. В статье изложен уникальный опыт государственного управления экономикой в условиях военного времени. Приводится факт, что если в 1940 году доля военной продукции составляла 17\% от общего выпуска, то в 1944 г. данный показатель достиг 51\%, что свидетельствует об успешности выполнения плана мобилизации. Один из моментов, оказывающих влияние на экономику военного времени описывает Войтович В.Ю. в работе [10]. Основываясь на архивных материалах, автор показывает роль социалистического соревнования в годы ВОВ, считая данное движение очень важным для мобилизации творческой энергии и развития производства в тылу. 
Подмарев А.А., в своей работе [11] рассматривает специфические признаки ограничений прав личности в условиях военного положения. При этом делается вывод о том, что ограничения прав и свобод гражданина, реализуемые в условиях военного положения, являются законными и позволяют увеличить полномочия органов государственного управления для лучшей управляемости. Исторический опыт введения военного налога на население в СССР во время Второй мировой войны описан в работе [12]. Так, показано, что данный налог имел прогрессивную шкалу удержания, в зависимости от заработка, и составлял примерно 10\% от заработной платы. Таким образом, в период войны было собрано средств от действия военного налога на сумму около 72,1 млрд. руб. В продолжение темы, в исследованиях $[13,14]$ рассмотрен исторический опыт наполнения государственного бюджетов и местного самоуправления в условиях мобилизационной экономики. В работе подробно представлена система налогов и сборов с населения, включая денежные государственные займы. Особое внимание уделено методам наполнения местных бюджетов в период войны 1941-1945 гг. и после нее, делаются вывод, что местное самоуправление в данный период получило достаточно полномочий для регулирования своих доходов. Проведенные расчеты авторов позволили сформулировать интересный вывод о том, что если сложить все виды налогов и платежей, уплачиваемых населением во время войны (прямые налоги, налог с оборота, государственные займы и т.д.), то за счет них обеспечивалось три четверти всех доходов государственного бюджета СССР.

\section{Материалы и методы исследования.}

Важным в определении изменения финансово-экономического положения регионов в военное время является изучение опыта Советского Союза в годы Великой отечественной войны и тех мероприятий, которые проводили органы государственной власти по управлению финансовой и банковской системой страны. В первые месяцы войны идет перераспределения расходных потоков. Существенно увеличиваются расходы бюджета на военные нужды: вы- 
плату заработной платы военнослужащим, пособия семьям в связи с уходом кормильца на фронт, на формирование новых армейских подразделений, эвакуацию и т.д. Наряду с этим в других сферах наблюдается сокращение расходов, в том числе заработной платы. Так, во втором полугодии 1941 г. в государственном бюджете страны военные расходы выросли на 20,6 млрд руб., а расходы на гражданские отрасли народного хозяйства сократились на 21,6 млрд руб. [15].

Согласно источникам [16,17], начало войны характеризовалось бесконтрольной эмиссией денег, которая была обусловлена отсутствием кассового плана и потребностью полевых учреждений Госбанка СССР. С целью сдержать объем эмиссии, вводятся ограничения по обращению наличной денежной массы: ограничения по выдаче вкладов из сберегательных касс, госзаймы и др. Происходит повышение цен на алкогольную и табачную продукцию, парфюмерию, с сохранением цен на основные товары и введением карточек на продажу последних.

Очевидно, что наряду с ростом расходов происходит снижение доходной части бюджета. Это связанно, в первую очередь, с тем, что на оккупированных западных территориях страны были расположены производства, на которые приходилось 64\% добычи угля, 58\% выплавки стали, 71\% производства чугуна, 60\% производства алюминия, а также значительная часть сельскохозяйственной продукции. Во-вторых, с падением розничного товарооборота [17].

В качестве антиинфляционных мер и мер по увеличению доходов бюджета был издан Указ Президиума Верховного совета СССР «Об установлении на военное время временной надбавки к сельскохозяйственному налогу и к подоходному налогу с населения» от 3 июля 1941 года. Для нельготных категорий населения налог был увеличен в два раза. Надбавка к сельскохозяйственному налогу и к подоходному налогу с населения просуществовала до 1942 года. После ее отмены был введен военный налог. Кроме того, с 21 ноября 1941 года вводится новый налог - на холостяков, одиноких и бездетных.

Наряду с введением налогов и ростом налоговых ставок, дополнительным и очень важным источником пополнения доходов 
бюджета - привлечение средств населения. Средства населения привлекались через государственные займы (процентные и беспроцентные), денежно-вещевые лотереи, Фонд обороны. Последний был создан в 1941 году, за время войны в него поступило 17,6 млрд руб. наличными деньгами, 13,2 кг платины, 131,4 кг золота, 9519 кг серебра, драгоценностей на 1,7 млрд руб . [17].Население жертвовало фронту не только в денежном выражении, но и в натуральной форме.

Однако все принятые меры в первый год войны не позволили избежать эмиссии и дефицита бюджета. По данным [17] масса денег в обращении на 01 января 1942 года по сравнению с началом войны выросла в два раза с 18,4 млрд руб. до 34,7 млрд руб., без учета средств на временно занятой территории - около 30 млрд руб., стоит отметить, что этот период характеризовался максимальной эмиссией за все время войны. Поскольку, по данным $[18,19]$ объем денежной массы в начале 1946 года по сравнению с довоенным значением превзошел в 3,8 раза. По итогам 1941 года государственный бюджет был сведен с дефицитом 14,5 млрд руб. Самое пиковое значение дефицита бюджета за годы войны было достигнуто в 1942 году - он составил 17,9 млрд руб. Начиная с 1943 года бюджет сводился с профицитом: 1943 г. - 5,6 млрд рублей; 1944 г. - 4,7 млрд рублей; 1945 г. - 3,4 млрд рублей.

В годы Великой отечественной войны еще одним важным направлением работы банковской и финансовой системы страны, начиная с переломного 1942 года, было поддержание функционирования экономики - налаживание работы эвакуированных предприятий, повышение уровня промышленного производства, а также снабжение продуктами питания. Поддержка осуществлялась посредством предоставления краткосрочных кредитов на льготных условиях, отсрочки погашения задолженности по банковским ссудам и др.

Среди особенностей кредитной политики в военные годы ученые выделяют ее направленность на развитие, в основном, промышленности и выпуском государственных займов на финансирование такого вида расходов. В Советском Союзе займы, размещались 
преимущественно среди населения, в отличие от стран-союзниц, которые привлекали средства банков и других денежно-кредитных учреждений [20].

Таким образом, опыт Великой Отечественной войны в финансовой сфере показывает, что финансирование военных нужд осуществлялось, в значительной степени, за счет сокращения доходов населения и эмиссии денежных средств.

На современном этапе, нарастание угрозы агрессии (санкционный режим) в финансово-экономической сфере фактически происходит с 2014 г., после присоединения полуострова Крым к Российской Федерации. В финансовом плане зарубежными странами (США, ЕС и т.д.) были введены ограничения по кредитованию «Сбербанка России», банка ВТБ, «Газпромбанка», «Внешэкономбанка», «Россельхозбанка». Также санкции затронули организацию долгового финансирования трёх топливно-энергетических компаний России: «Роснефти», «Транснефти», «Газпром нефти». Запрещены торговля облигациями этих компаний со сроком обращения свыше 30 дней и участие в организации выпусков таких бумаг. Такие же санкционные условия введены для трёх крупнейших оборонных концернов России: «Уралвагонзавода», «Оборонпрома», «Объединённой авиастроительной корпорации».

В современной литературе, посвященной введенным ограничениям по отношению к России, рассматриваются варианты противодействия санкционному режиму. В статье М.В. Рукинова [22], помимо анализа политики импортозамещения, предлагается, в качестве ответа на санкции, сформировать рынок сбыта отечественной высокотехнологической и сырьевой продукции в странах, проводящих независимую от Запада политику. По аналогии с мировой социалистической системы. В то же время автор признает и выделяет ряд проблем при использовании такого подхода (неплатежеспособность стран, узкий рынок для продукции и т.д.). В монографии по редакцией Р. М. Нуреева [23] довольно подробно рассматриваются экономические, политические и социальные предпосылки введения санкций против России. Рецепты выхода из них также предлагается 
в ключе развития промышленности и высокотехнологичного сектора экономики, с уклоном на директивные методы управления. В. С. Загашвили в работе [24] достаточно подробно описывает исторический аспект и эффективность санкционных режимов в мире, и отмечает, что они не оказали решающего значения на текущее состояние российской экономики, однако в средне и долгосрочной перспективе могут существенно ограничить экономический рост нашей страны. В другой статье [25] рассматриваются влияние санкций на экономические связи между Россией и Европейским Союзом. Отмечается, что данные действия отрицательно сказываются на экономическом развитии партнеров, хотя и в разной степени.

По разным оценкам, данные ограничительные действия в финансовой сфере не привели к крупным потерям в российской экономике, их оценивают в диапазоне от 0 до 1,5\% ВВП. Это неудивительно, поскольку режим санкций носит точечный характер, и не влияет на широкий круг финансовых взаимоотношений с мировым хозяйством, тем более что ряд развитых стран (Китай, Южная Корея и т.д.) не поддержали данные ограничения. Более весомым фактором в замедлении финансового и экономического развития выступило снижение цен на основные экспортные товары России - нефть и природный газ $[24,26]$. Зависимость российской экономики от доходов от экспорта углеводородов никем не оспаривается, однако колебания цен на нефть и природный газ является рыночным фактором, и не входит в состав агрессии со стороны других стран.

В региональном разрезе, на сегодняшний день введенные санкции против России, наиболее ярко отразились на экономическом развитии полуострова Крым, поскольку для него были введен отдельный пакет санкций со стороны Европейского Союза. Под запрет для европейских компаний попали покупка недвижимости и предприятий в Крыму, финансирование крымских компаний и предоставление связанных с эти услуг, оказание туристических услуг в Крыму. Также ЕС запретил поставки в Крым около 200 наименований товаров, в частности, технологии, которые касаются транспортного, телекоммуникационного и энергетического секторов, а также 
разведки и добычи газа, нефти и минеральных ресурсов, и драгоценные металлы и т.д. Данные ограничения несколько усложнили ведение нормальной хозяйственной деятельности российских и зарубежных компаний в Крыму, однако последствия нельзя признать фатальными. Для примера можно привести ситуацию с поставкой газотурбинных установок немецкой фирмы Siemens для первых энергоблоков Таврической и Балаклавской теплоэлектростанций (ТЭС), расположенных в Крыму. В этом случае, компания Siemens, опасаясь нарушения санкционного режима, судилась со структурами Ростеха, обвиняя в нарушении договоренностей при поставках ее газовых турбин. Немецкий концерн требовал возврата турбин, однако в итоге Siemens проиграл судебный спор, и это не помешало запустить ТЭС в работу.

Для других регионов явных последствий от введения санкций со стороны зарубежных стран не наблюдалось, в большей степени финансовые ограничения были нивелированы на федеральном уровне.

Возможное дальнейшее нарастание угрозы агрессии на Российскую Федерацию в виде санкций, как показывает опыт других стран и регионов, в финансово-экономической сфере может выражаться в усилении ограничений в финансовой сфере, по аналогии с другими странами, находящимися в данном режиме (например, КНДР, Иран, Венесуэла).

Поскольку «точечные» санкции в отношении РФ уже действуют, то следует ожидать, в случае нарастании агрессии, применение «фронтальных» санкций для хозяйствующих субъектов РФ, направленных на те или иные сферы деятельности народного хозяйства.

Наиболее обсуждаемые в экспертной среде ограничения, и, соответственно, наиболее вероятное развитие санкционного режима против России в финансово-экономической сфере могут коснуться следующих сфер деятельности:

1) Ограничение или полный запрет на кредитование российской экономики нерезидентами. Здесь могут быть широкие вариации применения таких санкций - от запрета на кредитование (в том или ином виде) отдельных квазигосударственных финансовых и 
нефинансовых компаний (например, Сбербанк, ВТБ и т.д.), государственного долга (ОФЗ), до полной «изоляции» российского финансового рынка от мирового финансового капитала. В данном случае, с учетом предпринятых мер на федеральном уровне по защите российского рынка (накопленные золотовалютные резервы, Фонд национального благосостояния, диверсификация резервов, скопление наличной валюты в банковской системе, низкий государственный и корпоративный долг перед нерезидентами и т.д.), влияние таких санкций не окажет разрушительного влияния на финансово-экономическую сферу. В то же время, возможное нарастание угроз по такому сценарию непременно окажет негативное влияние на возможности экономического развития России во всех сферах, особенно негативно скажется на курсе рубля по отношению к другим валютам. В данном варианте нарастания угроз наиболее заметное влияние в региональном разрезе санкции окажут на финансовые центры РФ гг. Москва и Санкт-Петербург, поскольку доля финансового сектора в добавленной стоимости других регионов не столь значительна.

2) Более серьезным вызовом для финансово-экономической сферы может стать отключение от международной межбанковской системы передачи информации и совершения платежей SWIFT (такие санкции в настоящее время применены к КНДР и Ирану). Для страховки от коллапса системы платежей, Банк России, начиная с декабря 2014 года, предоставляет кредитным организациям свою систему передачи финансовых сообщений (СПФС) в формате SWIFT для внутрироссийских операциях. По некоторым оценкам, доля внутреннего трафика (передачи финансовых сообщений между российскими организациями) составила около $80 \%$ от общего количества сообщений, отправляемых российскими пользователями SWIFT. Поэтому для внутренних платежей данная мера не будет особо чувствительной, однако возникнут проблемы по расчетам с зарубежными контрагентами, особенно с развитыми странами. Данный вид санкций тоже не является критичным для российской финансовоэкономической сферы, однако заметно усложнит внешнеэкономическую деятельность хозяйственных субъектов, а также повысит 
трансакционные издержки всей экономики. В региональном измерении, помимо финансовых центров РФ, негативное влияние на финансово-экономическое развитие будет ощущаться в экспортноориентированных регионах, поскольку затруднения в расчетах за поставленную продукцию ухудшит показатели экономического развития. В то же время, регионы, продукция которых пользуется спросом на внутреннем рынке, могут улучшить свое положение, поскольку включится механизм так называемого импортозамещения.

3) Ограничение или полное эмбарго на экспорт какой-либо продукции, в наиболее жестком варианте - полный разрыв экспортно-импортных операций с Российской Федерацией. Наиболее вероятным сценарием здесь выглядит введение эмбарго на экспорт углеводородного сырья (нефть, нефтепродукты, природный газ и т.д.), поскольку в существующих реалиях после карантинного восстановления мировой экономики, спрос на углеводороды заметно упал. Данный вид санкций, несомненно ухудшит финансово-экономическое состояние всех без исключений регионов нашей страны, поскольку, в первую очередь, снизятся доходы федерального бюджета, являющейся системообразующим для всей экономики в целом. Наиболее пострадавшими в этом варианте нарастания угроз выступят регионы, завязанные на технологический цикл производства и экспорта сырьевой продукции, начиная от Западной Сибири и заканчивая перевалочными регионами. В рамках нарастания агрессии данный вид санкций является наиболее опасным, поскольку может затронуть все сферы и все территории в плане ухудшения финансово-экономической ситуации, просто часть регионов почувствуют влияние санкций непосредственно (через снижение производства, сокращения рабочих мест и т.д.), другие - опосредованно (общее снижение уровня жизни, государственных субсидий и трансфертов). В наиболее уязвимом положении окажутся регионы, непосредственно связанные с введенными ограничениями, например при запрете на экспорт сельскохозяйственной продукции пострадают аграрные территории (Краснодарский край, Республика Алтай и т.д.), при этом другие регионы могут и сохранить стабильное развитие. 


\section{Результаты и их обсуждение}

Трансформация угроз финансового развития экономик субъектов Российской Федерации в период мобилизации будет определяться характером мероприятий, проводимых федеральными органами власти в рамках самой мобилизации. Поскольку опыта мобилизации в современной Российской Федерации не имеется, можно привести несколько моделей мобилизации, основанных на отечественном и международном опыте.

Модели мобилизации в социально-экономической сфере во всем мире достаточны схожи, и характеризуются концентрацией всех ресурсов для выполнения задач по подготовке страны к военному времени. В разных системах принципиальные отличия мобилизации заключаются в степени вмешательства государственных органов в процессы хозяйственного управления предприятиями и населения. То есть существуют модели от «государственного заказа» частным предприятиям в оборонно-промышленном комплексе и минимальным вмешательством в деятельность предприятий и граждан до полного тотального контроля над ресурсами в период мобилизации.

Как показывает опыт нашей страны, традиционно в период мобилизации используется наиболее эффективная модель (с организационной точки зрения) концентрации ресурсов государственными органами, с целью сосредоточения экономических, финансовых и производственных возможностей для подготовки к военному времени.

В этих условиях, в период мобилизации, можно предположить следующие изменения в финансово-экономической сфере государства и регионов:

- централизация финансовых ресурсов средств предприятий на счетах Центрального Банка, ограничение расчетов с зарубежными контрагентами;

- ограничение по выдаче, либо замораживание средств граждан по текущим и сберегательным счетам;

- запрет на конвертацию средств в валюту, ограничение переводов денежных средств за рубеж; 
- частичная или полная национализация компаний, имеющих важное значение для военного времени;

- введение внутренней (условной) системы цен для предприятий, занятых в мобилизационной подготовке;

- резкое увеличение расходов бюджетов всех уровней на военные расходы, увеличение эмиссии Центрального Банка;

- введение новых налогов и обязательных платежей для негосударственного бизнеса и населения, с целью компенсировать расходы на мобилизационную подготовку;

- введение принципа нормативности расходов регионального и местных бюджетов, в зависимости от количества населения, централизация бюджетных расходов.

Соответственно, период мобилизации скажется на финансовоэкономическом состоянии разнонаправлено, в зависимости от специализации и вида производимых товаров и услуг. Наиболее пострадавшими от мобилизационных действий могут стать территории ресурсного типа, поскольку высокий уровень развития в мирное время будет снижаться за счет изъятия ресурсов на мобилизационную подготовку. К этим территориям можно отнести практически все Арктические территории, столичные субъекты федерации, аграрные территории. Позитивный импульс развития могут получить те регионы, которые связаны с военно-промышленным комплексом, за счет получения новых заказов, развертывания мобилизационных мощностей и притока населения. К ним можно отнести часть регионов Центрального федерального округа (г. Москва, Владимирская, Воронежская, Тульская области), большинство территорий Приволжского и Уральского федеральных округов, где сосредоточены основные мощности оборонной промышленности. Немного менее значительные преимущества могут получить регионы Сибирского федерального округа (Иркутская, Омская области и Красноярский край), а в Дальневосточном федеральном округе ряд стратегически важных предприятий расположены в Республике Бурятия, Приморском и Хабаровском краях. В остальных регионах, напрямую не связанных с мобилизационной подготовкой, возможно снижение 
параметров финансово-экономического развития, за счет общих ограничений в экономике.

Трансформация угроз финансового развития экономик субъектов Российской Федерации в военное время

Финансово-экономическое развитие регионов в военное время будет характеризоваться изменениями тех или иных показателей, в зависимости от течения и характера военного театра действий. В целом, исходя из предыдущего опыта, можно предположить следующие изменения в финансово-экономической сфере государства и регионов в военное время:

- резкое увеличение расходов бюджетов всех уровней на военные нужды, в первую очередь федерального бюджета;

- снижение расходов на социальное обеспечение, здравоохранение и образование;

- нормирование оплаты труда, в зависимости от отраслевых факторов, выравнивание уровня заработных плат среди регионов;

- государственная монополизация внешнеэкономической деятельности, импортно-экспортных операций, запрет на свободный оборот части товаров и материалов;

- денежная эмиссия Центральным банком для покрытия дефицита бюджета, нарастание инфляционных процессов;

- в случае неблагоприятного развития военных действий - потеря финансовой системой обменной функции, переход на натуральный обмен и распределительную систему товаров и услуг;

- нарушение товарно-обменных операций как с зарубежными странами, так и между регионами и территориями.

В региональном разрезе наибольшую опасность экономического коллапса представляют собой регионы, на территории которых ведутся боевые действия. В первую очередь это могут быть приграничные территории и эксклавные регионы (в первую очередь Калининградская область). В этом случае нарушаются практически все условия ведения хозяйственной деятельности, территория перехо- 
дит в ведение военных органов власти. Наибольшее преимущество, конечно относительное, в период военного времени получают регионы с развитым военно-промышленным комплексом и территории, на которых возможно ведение подсобного сельского хозяйства - это практически все регионы Южного, Центрального, Северо-Кавказского федеральных округов. Также южные регионы Уральского, Сибирского и Дальневосточного округов. При нарушении нормального финансово-экономического оборота в сложное положение могут попасть регионы Севера и Арктики, поскольку выживание и развитие территорий будет зависеть от степени налаженности их обеспечения материально-техническими ресурсами и продовольствием.

\section{Заключение}

В целом, режимы мобилизации и военного времени характеризуется резкими изменениями условий в финансово-экономических отношениях, снижением значимости самой финансовой системы и рыночных отношений. В этих условиях, региональное благополучие в финансово-экономической сфере будет определяться степенью важности и ценности размещенных на территории предприятий для обеспечения военных нужд. Стоит выделить основные угрозы введения чрезвычайных мер в такие периоды для финансовой сферы и их влияние на экономику субъектов РФ.

1) Ограничение или полный запрет на кредитование российской экономики нерезидентами, который затронет все регионы РФ, наиболее пострадавшими могут оказаться финансовые центры страны. В то же время у центрального правительства имеются все ресурсы для снижения негативного воздействия данной угрозы через регулятивное воздействие Центральным Банком РФ.

2) Отключение от международной межбанковской системы передачи информации и совершения платежей SWIFT. В данном случае наибольший удар придется на регионы, связанные с экспортом природных ресурсов и импортом товаров. Благодаря развитию собственных платежных систем в последние годы, внутренние расчеты не будут подвержены негативному воздействию. 
3) Ограничение или полное эмбарго на экспорт какой-либо продукции окажет сильнейшее воздействие на регионы, продукция которых попадет под ограничения. В случае применения эмбарго на весь ассортимент продукции Российской Федерации, в более выигрышном положении окажутся территории, продукция которых ориентирована на внутренний рынок.

4) Централизация финансовых ресурсов средств предприятий на счетах Центрального Банка, ограничение расчетов с зарубежными контрагентами, данный сценарий вероятен при мобилизации. В относительно благоприятном положении окажутся регионы с военной промышленностью и добычи стратегических ресурсов.

5) Нарушение товарно-обменных операций как с зарубежными странами, так и между регионами и территориями, характерное для военного времени. В данном случае наиболее устойчивыми окажутся сельскохозяйственные территории, поскольку они смогут обеспечить порог своего выживания.

Благодарность. Публикация подготовлена в соответствие с государственным заданием для ФГБУН Института экономики УрО РАН на 2020-2022 гг.

\section{Список литературы}

1. Алешин В.В. Военное и чрезвычайное положения как специальные правовые режимы обеспечения национальной безопасности Российской Федерации // Право и образование. 2014. № 11. С. 87-95. URL: https://elibrary.ru/item.asp?id=22412876.

2. Зиборов О.В. Статическое и динамическое проявления административно-правового режима военного положения // Юридическая наука и правоохранительная практика. 2015. №1(31). C. 16-21. URL: https://elibrary.ru/item.asp?id=23701422.

3. Григорьев В.Н. Особые правовые режимы: вопросы соответствия Конституции // Вестник Томского государственного университета. Право. 2015. №4 (18). C. 22-29. URL: https://elibrary.ru/item. asp?id=24988832. DOI 10.17223/22253513/18/3 
4. Утяшов Э.К. Правовое регулирование режима военного положения в Республике Беларусь и Российской Федерации: сравнительноправовой анализ // Журнал Белорусского государственного университета . Право. 2018. № 1. С. 36-45. URL: https://elibrary.ru/item. asp? $\mathrm{id}=36715757$.

5. Сорокин А.Н. Комитеты ученых Сибири в годы Великой Отечественной войны // История в подробностях. 2010. № 1. С. 58-65. URL: https://elibrary.ru/item.asp?id=15620762.

6. Рощин Б.Е. Специфика советского трудового законодательства в годы Великой отечественной войны // Вестник КГУ им. Н.А. Некрасова. 2015. № 4. C. 210-214. URL: https://elibrary.ru/item.asp?id=24293273.

7. Лактюнкина Т.Э. Влияние Первой мировой войны на социальноэкономическое положение Оренбургской губернии // Исторические, философские, политические и юридические науки, культурология и искусствоведение. Вопросы теории и практики. 2014. № 10 (48). C. 119-122. URL: https://elibrary.ru/item.asp?id=21976629.

8. Невская Н.А. Опыт планового управления в условиях военной экономики: Госплан СССР во времена ВОВ // ЦИТИСЭ. 2015. №3 С. 1-6. URL: https://elibrary.ru/item.asp?id=24952309.

9. Невская Н.А. Планирование и экономика военного времени в СССР (1941-1945 гг.) // ЦИТИСЭ. 2015. №4. С. 1-6. URL: https://elibrary. $\mathrm{ru} / \mathrm{item} . \mathrm{asp}$ ?id=25345870.

10. Войтович В.Ю. Роль социалистического соревнования в годы Великой отечественной войны (1941-1945 гг.) (на материалах Удмуртии) // Научное обозрение. Экономические науки. 2017. № 3. С. 105-111. URL: https://elibrary.ru/item.asp?id=29253615.

11. Подмарев A.A. Ограничение прав и свобод человека и гражданина в условиях военного положения в Российской Федерации // Изв. Сарат. ун-та. Нов. сер. Сер. Экономика. Управление. Право. 2018. Т. 18, вып. 1. C. 96-100. URL: https://elibrary.ru/item.asp?id=35125141. DOI: 10.18500/1994-2540-2018-18-1-96-100.

12. Лесничий В.В., Григорьев И.А. Военный налог как способ эффективной мобилизации средств на военную экономику. Исторический анализ военного налога в советском союзе во время Великой 
отечественной войны // Научные проблемы материально-технического обеспечения вооруженных сил Российской Федерации. 2019. №1(11). C. 137-144. URL: https://elibrary.ru/item.asp?id=37315358.

13. Караваева И.В., Козлова С.В. Феномен расширения финансовой самостоятельности органов местного управления в условиях мобилизационной экономики // Экономическая безопасность. 2020. Том 3. № 1. C. 14-30. URL: https://1economic.ru/lib/110118. DOI: 10.18334/ ecsec.3.1.110118

14. Караваева И.В. Военная экономика России в первой половине XX столетия. / под ред. И.В. Караваевой. М.: ИЭ РАН, 2006. 184 с.

15. Советский Союз в годы в годы Великой Отечественной войны. М., 1976. $84 \mathrm{c}$.

16. Селеев С. Военно-полевые финансы// Коммерсантъ «Деньги» №17 (https://kommersant.ru/money/109924) от 06.05.2017 URL: https:// www.kommersant.ru/doc/3273720\#id1424120.

17. Алексеев А. Цена Победы// Коммерсантъ «Деньги». Приложение №28 от 25.06.2019, стр. 42 URL: https://www.kommersant.ru/doc/4004614.

18. Кумзеров В. Финансы СССР в годы Великой Отечественной войны URL: https://proza.ru/2018/12/02/1187.

19. Муравьева Л.А. Модернизация экономики и финансов СССР в годы Великой Отечественной войны // Модернизация современного общества: проблемы, пути развития и перспективы. 2015. № 6. С. 20 28 URL: https://elibrary.ru/item.asp?id=23405069.

20. Муравьева Л.А. Финансы СССР в годы Великой Отечественной войны// Финансы и кредит. 2004. №14(152). C. 83-91 URL: https:// elibrary.ru/item.asp?id $=9305732$

21.Киреева Е.В. Тренды в сфере государственных финансов: вызовы, реальность, перспективы // Экономика и предпринимательство. 2020. № 3 (116). C. 158-163. DOI: 10.34925/EIP.2020.116.3.030

22. Рукинов М.В. Антироссийские санкции: структура и стратегии противодействия // Управленческое консультирование. 2019. № 6. С. 91-101. DOI 10.22394/1726-1139-2019-6-91-101

23. Арефьев П.В., Альпидовская М.Л., Блинов А.О., Данилова О.В., Карасева Л.А., Кузнецов А.В., Мальцев В.В., Нуреев Р.М., Петраков 
П.К., Слепаков С.С., Соколов Д.П., Степин Е.А., Чусовлянов Д.С. Экономические санкции против России: ожидания и реальность. М.: КноРус, 2017. 194 c. https://elibrary.ru/item.asp?id=27626510

24. Загашвили В.С. Западные санкции и российская экономика // Мировая экономика и международные отношения. 2015. Т. 59. № 11. C. $67-77$. https://elibrary.ru/item.asp?id=25054543

25. Клинова М.В., Сидорова Е.А. Экономические санкции и их влияние на хозяйственные связи России с Европейским Союзом // Вопросы экономики. 2014. № 12. С. 67-79. DOI 10.32609/0042-8736-2014-1267-79 https://elibrary.ru/item.asp?id=22619838

26. Kudrin A., Knobel A. Russian budget structure efficiency: empirical study // Russian Journal of Economics. 2018, vol. 4. № 3. pp. 197-214. DOI 10.3897/j.ruje.4.30163 https://elibrary.ru/item.asp?id=35639176

\section{References}

1. Aleshin V.V. Voennoe i chrezvychaynoe polozheniya kak spetsial'nye pravovye rezhimy obespecheniya natsional'noy bezopasnosti Rossiyskoy Federatsii [Martial law and state of emergency as special legal regimes for ensuring the national security of the Russian Federation]. Pravo $i$ obrazovanie, 2014, № 11, pp. 87-95. URL: https://elibrary.ru/item.as$\mathrm{p}$ ? id $=22412876$.

2. Ziborov O.V. Staticheskoe i dinamicheskoe proyavleniya administrativno-pravovogo rezhima voennogo polozheniya [Static and dynamic manifestations of the administrative-legal regime of martial law]. Yuridicheskaya nauka i pravookhranitel'naya praktika, 2015, №1(31), pp. 16-21. URL: https://elibrary.ru/item.asp?id=23701422.

3. Grigor'ev V.N. Osobye pravovye rezhimy: voprosy sootvetstviya Konstitutsii [Special legal regimes: issues of compliance with the Constitution]. Vestnik Tomskogo gosudarstvennogo universiteta. Pravo, 2015, №4 (18), pp. 22-29. URL: https://elibrary.ru/item.asp?id=24988832. DOI $10.17223 / 22253513 / 18 / 3$

4. Utjashov E. K. Pravovoe regulirovanie rezhima voennogo polozheniya v Respublike Belarus' i Rossiyskoy Federatsii: sravnitel'no-pravovoy analiz [Legal regulation of martial law in the Republic of Belarus and the 
Russian Federation: comparative analysis]. J. Belarus. State Univ. Law, 2018, No. 1, pp. 36-45. URL: https://elibrary.ru/item.asp?id=36715757.

5. Sorokin A.N. Komitety uchenykh Sibiri v gody Velikoy Otechestvennoy voyny [Committees of Siberian Scientists during the Great Patriotic War]. Istoriya v podrobnostyakh, 2010, № 1, pp. 58-65. URL: https:// elibrary.ru/item.asp?id=15620762.

6. Roshchin B.E. Spetsifika sovetskogo trudovogo zakonodatel'stva $v$ gody Velikoy otechestvennoy voyny [Specificity of Soviet labor legislation during the Great Patriotic War]. Vestnik KGUim. N.A. Nekrasova, 2015, № 4, pp. 210-214. URL: https://elibrary.ru/item.asp?id=24293273.

7. Laktyunkina T.E. Vliyanie Pervoy mirovoy voyny na sotsial'no-ekonomicheskoe polozhenie Orenburgskoy gubernii [Influence of the First World War on the socio-economic situation of the Orenburg province]. Istoricheskie, filosofskie, politicheskie i yuridicheskie nauki, kul'turologiya $i$ iskusstvovedenie. Voprosy teorii i praktiki, 2014, № 10 (48), pp. 119-122. URL: https://elibrary.ru/item.asp?id=21976629.

8. Nevskaya N.A. Opyt planovogo upravleniya v usloviyakh voennoy ekonomiki: Gosplan SSSR vo vremena VOV [The experience of planned management in a military economy: the State Planning Committee of the USSR during the Second World War]. TSITISE, 2015, №3, pp. 1-6. URL: https://elibrary.ru/item.asp?id=24952309.

9. Nevskaya N.A. Planirovanie i ekonomika voennogo vremeni v SSSR (1941-1945 gg.) [Wartime planning and economics in the USSR (19411945)]. TSITISE, 2015, №4, pp. 1-6. URL: https://elibrary.ru/item.as$\mathrm{p} ? \mathrm{id}=25345870$.

10. Voytovich V.Yu. Rol'sotsialisticheskogo sorevnovaniya v gody Velikoy otechestvennoy voyny (1941-1945 gg.) (na materialakh Udmurtii) [The role of socialist competition during the Great Patriotic War (1941-1945) (based on materials from Udmurtia)]. Nauchnoe obozrenie. Ekonomicheskie nauki, 2017, № 3, pp. 105-111. URL: https://elibrary.ru/item. asp? id=29253615.

11. Podmarev A.A. Ogranichenie prav i svobod cheloveka i grazhdanina v usloviyakh voennogo polozheniya v Rossiyskoy Federatsii [Restriction of human and civil rights and freedoms under martial law in the Rus- 
sian Federation]. Izv. Sarat. un-ta. Nov. ser. Ser. Ekonomika. Upravlenie. Pravo, 2018, Vol. 18.№ 1, pp. 96-100. URL: https://elibrary.ru/item. asp?id=35125141. DOI: 10.18500/1994-2540-2018-18-1-96-100.

12.Lesnichiy V.V., Grigor'ev I.A. Voennyy nalog kak sposob effektivnoy mobilizatsii sredstv na voennuyu ekonomiku. Istoricheskiy analiz voennogo naloga v sovetskom soyuze vo vremya Velikoy otechestvennoy voyny [War tax as a way to effectively mobilize funds for the military economy. Historical analysis of the war tax in the Soviet Union during the Great Patriotic War]. Nauchnye problemy material'no-tekhnicheskogo obespecheniya vooruzhennykh sil Rossiyskoy Federatsii, 2019, №1(11), pp. 137-144. URL: https://elibrary.ru/item.asp?id=37315358.

13. Karavaeva I.V., Kozlova S.V. Fenomen rasshireniya finansovoy samostoyatelnosti organov mestnogoupravleniya $\mathrm{v}$ usloviyakh mobilizatsionnoy ekonomiki [The phenomenon of enhancing financial independence of the local government bodies in the conditions of mobilization economy]. Ekonomicheskaya bezopasnost, 2020, № 3.(1), pp. 13-30. URL: https://1economic.ru/lib/110118. DOI: 10.18334/ecsec.3.1.110118.

14. Karavaeva I.V. Voennaya ekonomika Rossii v pervoy polovine KhKh stoletiya [War economy of Russia in the first half of the twentieth century]. Moscow: IE RAN, 2006, 184 p.

15. Sovetskiy Soyuz v gody v gody Velikoy Otechestvennoy voyny [Soviet Union during the years of the Great Patriotic War]. M, 1976, 84 p.

16. Seleev S. Voenno-polevye finansy [Military field finance]. Kommersant” "Den'gi” №17. 06.05.2017. https://www.kommersant.ru/ doc/3273720\#id1424120

17. Alekseev A. Tsena Pobedy [Victory Price]. Kommersant" "Den'gi". Prilozhenie №28, 25.06.2019, p. 42. https://www.kommersant.ru/ doc/4004614

18. Kumzerov V. Finansy SSSR v gody Velikoy Otechestvennoy voyny [Finances of the USSR during the Great Patriotic War]. https://proza. $\mathrm{ru} / 2018 / 12 / 02 / 1187$

19. Murav'eva L.A. Modernizatsiya ekonomiki i finansov SSSR v gody Velikoy Otechestvennoy voyny [Modernization of the economy and finance of the USSR during the Great Patriotic War]. Modernizatsiya sovremen- 
nogo obshchestva: problemy, puti razvitiya i perspektivy, 2015, № 6, pp. 20-28 URL: https://elibrary.ru/item.asp?id=23405069.

20. Murav'eva L.A. Finansy SSSR v gody Velikoy Otechestvennoy voyny [Finances of the USSR during the Great Patriotic War]. Finansy $i$ kredit, 2004, №14 (152), pp. 83-91 URL: https://elibrary.ru/item.as$\mathrm{p}$ ?id=9305732

21. Kireeva E.V. Trendy v sfere gosudarstvennyh finansov: vyzovy, real'nost', perspektivy [Trends in Public Finance: Challenges, Reality, Prospects]. Jekonomika i predprinimatel’stvo, 2020, № 3 (116), pp. 158163. DOI: 10.34925/EIP.2020.116.3.030

22. Rukinov M.V. Antirossijskie sankcii: struktura i strategii protivodejstvija [Anti-Russian Sanctions: Structure and Strategies of Counter-Action]. Upravlencheskoe konsul'tirovanie, 2019, № 6, pp. 91-101. DOI 10.22394/1726-1139-2019-6-91-101 https://elibrary.ru/item.as$\mathrm{p} ? \mathrm{id}=38597318$

23. Aref'ev P.V., Al'pidovskaja M.L., Blinov A.O., Danilova O.V., Karaseva L.A., Kuznecov A.V., Mal'cev V.V., Nureev R.M., Petrakov P.K., Slepakov S.S., Sokolov D.P., Stepin E.A., Chusovljanov D.S. Jekonomicheskie sankcii protiv Rossii: ozhidanija i real'nost' [Economic Sanctions against Russia: Expectations and Reality]. Moscow: KNORUS Publ., 2017. 194 p. https://elibrary.ru/item.asp?id=27626510

24.Zagashvili V.S. Загашвили B.C. Zapadnye sankcii i rossijskaja jekonomika [Western sanctions and Russian economy memo]. Mirovaja jekonomika i mezhdunarodnye otnoshenija, 2015, vol. 59, № 11, pp. 67-77 https://elibrary.ru/item.asp?id=25054543

25. Klinova M., Sidorova E. Jekonomicheskie sankcii i ih vlijanie na hozjajstvennye svjazi Rossii s Evropejskim Sojuzom [Economic Sanctions and EU-Russia Economic Relations]. Voprosy Ekonomiki, 2014, №12, pp. 67-79. DOI 10.32609/0042-8736-2014-12-67-79 https://elibrary.ru/ item.asp? $\mathrm{id}=22619838$

26.Kudrin A., Knobel A. Russian budget structure efficiency: empirical study. Russian Journal of Economics. 2018, vol. 4. № 3, pp. 197-214 DOI 10.3897/j.ruje.4.30163 https://elibrary.ru/item.as$\mathrm{p} ? \mathrm{id}=35639176$ 


\section{ДАННЫЕ ОБ АВТОРЕ}

Захарчук Екатерина Александровна, кандидат экономических наук, доцент; руководитель Центра стратегического развития территорий ФГБУН Институт экономики УрО РАН ул. Московская, 29, г. Екатеринбург, 620014, Российская Федерачия zakhartchouk@mail.ru

\section{DATA ABOUT THE AUTHOR}

Zakharchuk Ekaterina Aleksandrovna, candidate of economic sciences, associate professor; Head of the Center for Strategic Development of Territories

Institute of Economics of the Ural Branch of the Russian Academy of Sciences

29, Moskovskaya str., Yekaterinburg, 620014, Russian Federation zakhartchouk@mail.ru

SPIN-code: 9749-2835

ORCID: 0000-0001-5546-8127

ResearcherID: L-6771-2017

Scopus Author ID: 57190412267 